\title{
Dialogiske læringsrum med plads til hjerne og hjerte
}

\author{
Eva Ulstrup, Ekstern lektor, Roskilde Universitet og Mai-Britt Haugaard Jeppesen, konsulent, \\ Kobenhavns Kommune
}

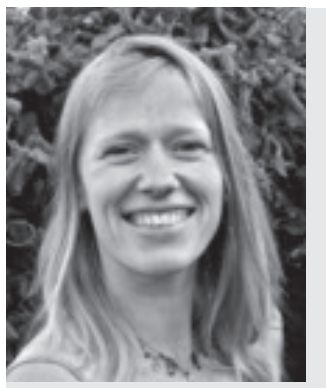

Eva Ulstrup, cand. mag. i psykologi og kommunikation. Ekstern lektor på Kommunikation, RUC, hvor hun underviser i mundtlig formidling og tekst/billede kommunikation. Ekstern lektor på LFK og University College Sjælland. Partner og kursusleder i kursusvirksomheden Flow Factory.

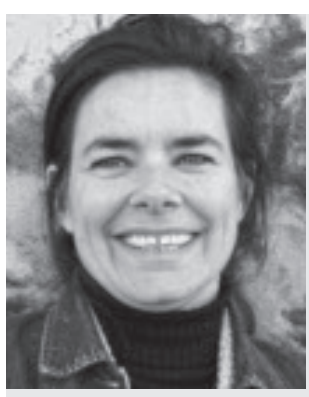

Mai-Britt Haugaard Jeppesen, cand. mag i Kultur- og Sprogmødestudier og Kommunikation. Konsulent i TaskForce Integration, Københavns Kommune

Pa bachelormodulet, Kommunikation, RUC, er der tradition for at afprove alternative måder at undervise på. Semestret er delt $i$ tre dele: workshops, forelasninger og projektskrivning. Foreløbige evalueringer viser, at størstedelen af de studerende vurderer udbyttet af hver workshop som "meget hojt«. Desuden har modulet som helhed en gennemforelsesprocent på over $95 \%$. På dette modul er der udviklet forskellige didaktiske redskaber. I denne artikel presenteres et lille udsnit af disse $i$ håbet om at inspirere andre til at gå nye veje $i$ undervisningen og at skabe dialogiske laringsrum.

Vi er optagede af at afprøve didaktiske redskaber i forsøget på at skabe en undervisningsramme, som inkluderer de studerende aktivt i undervisningssituationen og dermed fremmer læringspotentiale.

Målet med artiklen er at præsentere vore erfaringer med at skabe dialogiske læringsrum og beskrive et udsnit af de redskaber, vi anvender. Derudover er det vores håb, at artiklen kan inspirere til yderligere undersøgelse af alternativer til de mere traditionelle undervisningsrammer i andre fagspecifikke sammenhænge end vore.

Artiklen tager udgangspunkt i vore erfaringer fra bachelormodulet i kommunikation, RUC. Undervisningsforløbene, vi henviser til, strækker sig over tre ugers workshopforløb i skriftlig eller mundtlig kommunikation med ca. 18 studerende pr. workshop. Workshopperne afsluttes med en praktisk afprøvning, det kan f.eks. være at holde tale for ca. 200 medstuderende, eller at skabe et skriftligt kommunikationsprodukt med tilhørende akademisk redegørelse. De præsenterede redskaber har vi afprøvet i syv workshops.

På Kommunikation, bachelormodulet, er målet med workshopformen, at de studerende ved at producere, afprøve og analysere kommunikation tilegner sig kommunikationsfaglige begreber, teorier og metoder og kan anvende disse praktisk i arbejdet med kommunikation.Vi forsøger derfor at være kreative og nytænke undervisningen, så den lever op til de krav, som stilles til de studerende gennem studieordningen, og samtidig lever op til de overordnede krav, som forventes af akademikere, bl.a. at de skal være producerende og kritisk reflekterende.

\section{Det hele menneske og et sociokulturelt perspektiv}

Vores læringssyn er især inspireret af Olga Dysthes ${ }^{1}$ forståelse af et sociokulturelt læringsperspektiv (f.eks. Dysthe 1997, 2003), der sætter dialog i centrum for læringsprocesser og Knud Illeris'2 Udviklede Læringsteori (Illeris 2006, 2007).

Med afsæt i en sociokulturel forståelse af læring og Illeris' læringsteori har vi et konstruktivistisk syn på læring forstået på den måde, at vi både ser den studerende som konstruktør af egen læring og samtidig ser læring som en proces, der konstrueres gennem social interaktion i konkrete kontekster ${ }^{3}$. Dette kobles til en forståelse af de studerende som hele mennesker og 
ikke bare intellekter, der skal udvikles. Det betyder, at vi som undervisere skal tænke det kognitive, det følelsesmæssige, det sociale og det kropslige aspekt med $i$ undervisningen.

Vi forstår således undervisningssituationen ud fra et helhedssyn, hvor underviserens rolle ikke blot er fageksperten, som formidler faglighed, men ligeledes fungerer som facilitator, igangsætter, ordstyrer m.m. af læringsprocesser, der engagerer og skaber social og faglig dialog. I det følgende afsnit vil vi præsentere fire didaktiske redskaber, som vi har brugt i vores undervisning $\mathrm{i}$ forsøget på at tage konsekvensen af vores teoretiske positionering.

\section{Didaktiske redskaber - skrivningens læringspotentiale}

At skrive for at lære bygger på Vygotskys idé om, at tanken skabes gennem sproget (Dysthe 2001, Dysthe 2003). Skrivning kan være en hjælp til at »finde frem til, udvikle og organisere tanker" (Dysthe 2001: 66); altså til at konstruere læring. Skrivning giver plads til, at den enkelte kan fordybe sig uden at blive afbrudt, og så styrker det hukommelsen og fastholder tanker. For at benytte det læringspotentiale, som ligger i skrivningen, har vi udviklet en logbog til vores undervisning.

Logbogen fungerer på flere niveauer og indeholder forskellige typer arbejdspapirer. Nogle har til hensigt at sætte gang i refleksioner om og samtidig fastholde det faglige indhold, som formidles på forskellig vis $i$ undervisningen. Ved at stille åbne spørgsmål $i$ logbogen f.eks. "Skriv de vigtigste pointer fra det oplog du lige har hort " eller "Forklar begrebet afsenderhierarki og argumenter for hvorfor det er relevant "forsøger vi at opmuntre de studerende til ikke blot at referere men at reformulere

\section{Figur 1}

\section{Worksheet 4}

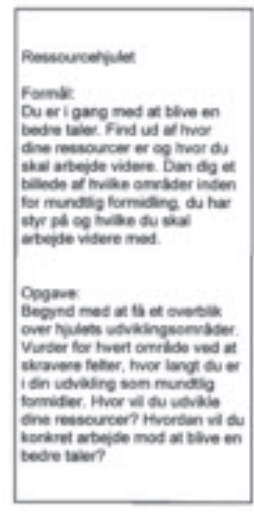

den viden, de er blevet præsenteret for. At reformulere er i følge Dysthe, første skridt på vejen til at gøre stoffet til sit eget (Dysthe 2001: 22).

Denne type arbejdspapirer er lineært opbygget. Det er A4 ark, som alle har en overskrift eller et spørgsmål, som skal besvares på blank side nedenfor. De studerende kan selv vælge, om de vil skrive i sætninger, i stikord, lave mindmaps eller andet. De fleste vælger den lineære skriveform, mens andre går anderledes til værks og laver mindmaps eller skemaer. Inden for læringsstilsforskning argumenteres der for, at nogle mennesker er analytisk anlagt, mens andre er mere holistisk orienterede i deres tilgang til læring, og netop når siderne er blanke og logbogen er individuel, tilgodeses de studerendes individuelle læringsstile.

For at udfordre og skabe mulighed for nye forståelse, tilbyder logbogen andre muligheder end det lineære. Det kan hjælpe de studerende til at løsrive sig fra præsentationsskrivning - den grammatisk korrekte skrivning - så de tør "tænkeskrive", hvilket giver mulighed for, at refleksionerne kan gå nye veje. Samtidig kan visuel opsætning give overblik på en anden måde end lineær form. Hvad der er mest hensigtsmæssigt afhænger af f.eks. tidspunkt og kontekst.

Vi har efterhånden udviklet en del forskellige visuelle A3 arbejdspapirer. Eksemplet i figur 1 »Kompetencehjulet« er fra undervisning i mundtlig kommunikation. Hensigten med dette arbejdspapir er, at den studerende får reflekteret over sine kompetencer og tager større ansvar for egen læring.

Hvert "lagkagestykke« repræsenterer en kompetence indenfor faget, f.eks. argumentation, gestik, artikulation og struktur. De studerende skraverer lagkagestykkerne, så det svarer til det, de selv oplever som deres faglige niveau, (på baggrund af feedback fra underviser og
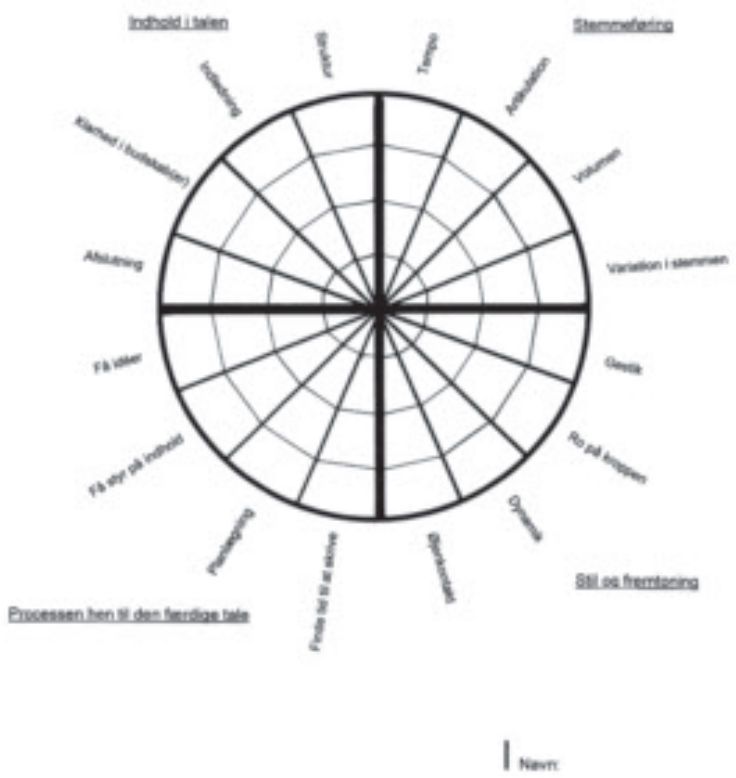
medstuderende samt egne erfaringer). Hvis de studerende oplever, at de behersker et område, skraverer de det helt. Hvis de synes, at de stadig mangler meget viden og kunnen, skraverer de kun det første stykke fra midten. De kan frit skrive refleksioner og stikord ned på arbejdspapiret. På den måde hjælper det dem til at reflektere over deres faglige kompetencer og få overblik over deres faglige styrker og svagheder. Arbejdet med kompetencehjulet afsluttes med samtaler om, hvordan den enkelte kan arbejde videre med de område, hvor hun er udfordret.

Logbøgerne er private. Det skrevne er ikke en færdig tekst, andre skal kunne læse og forstå. Det er »en uformel, udforskende skrivning omkring et tema" (Dysthe 2001: 43), som støtter de studerende $i$ konstruktion af viden, $i$ at se nye sammenhænge og $i$ at opnå ny erkendelse eller indsigt (Dysthe 2001:16).

\section{Spørgsmål som opfordrer til dialog}

Til idealet for et dialogisk læringsrum hører jævnlig, livlig og engageret debat og udveksling mellem alle i lokalet.Vi inviterer til talt dialog på flere måder.

Et redskab er forskellige spørgsmålstyper: Autentiske spørgsmål (Dysthe 1997:63) som er åbne spørgsmål, der lægger op til refleksion og giver plads til flere perspektiver. Det kan eksempelvis være "Hvad mener I, karakteriserer god faglig formidling?«. Disse spørgsmål lægger op til flere svar, der kan supplere hinanden. Brugen af autentiske spørgsmål kræver, at vi som undervisere giver afkald på ekspertrollen og i stedet påtager os rollen som igangsæettere af et fælles refleksionsforum. For at hjælpe refleksionen videre og samtidig sikre et højt fagligt niveau benytter vi optag og høj voerdsctning (Dysthe 1997:63). Det handler om at anerkende de studerendes deltagelse ved at tage fat i deres ytringer og bygge videre på dem for derved at kvalificere den viden, som kommer i spil.Vi har som undervisere ansvaret for det faglige niveau, og netop i fælles dialoger må vi ikke slippe det ansvar.Vi skal være vågne stilladsbyggere $^{4}$ og hele tiden sørge for, at det begrebsapparat, som hører til det faglige område vi bevæger os inden for, er i spil, som tovholdere i selve diskussionerne og ved at inddrage pointer fra fællesdiskussionerne i den videre formidling.

\section{Alle skal tale}

Når en workshop begynder, er det normalt kun få af de studerende, der tager ordet i fælles forum. Gennem systematisk arbejde med den talte dialog i læringsrummet, ændrer dette billede sig i løbet af fă dage. Halvvejs gennem det tre uger lange forløb er langt de fleste deltagende. Og i slutningen af workshoppen kan vi konstatere, at alle bidrager aktivt og engageret. I denne proces anvender vi forskellige pædagogiske værktøjer.

En af vore favoritter kaldes summemøder (Herskin
1995, 1997). Et summemøde varer kun $2-5$ minutter, men det er effektivt, fordi det "tvinger" alle til at gå i dialog med stoffet. Når vi som undervisere ønsker at sætte en mundtlig dialog i gang, beder vi de studerende om at drøfte diskussionsspørgsmålet med deres sidemand, for vi diskuterer i plenum. På den måde får alle mulighed for at diskutere emnet. Når vi efterfølgende diskuterer emnet i plenum, er der altid langt flere, der deltager, dels fordi alle har forholdt sig aktivt til stoffet, dels fordi det giver sikkerhed og motivation at have vendt emnet med andre først.

Vi benytter os af runder, hvor alle på skift kommenterer på et givent emne. Det er en teknik, som især er anvendelig i workshopsammenhæng med under 20 deltagere. Fordelen er, at alle får taletid og alle bliver hørt.Vi oplever det som en fordel jævnligt at tage runder, fordi det udjævner lidt af den magtfordeling, der opstår, når mennesker er samlet $\mathrm{i}$ en gruppe. Temaet for vores runder har blandt andet været evaluering eller vigtige pointer ved et netop afsluttet oplæg. Runder kan handle om hvad som helst, der giver mening $\mathrm{i}$ konteksten.

\section{Få kroppen med}

Ud over de talte og de skrevne dialoger inddrager vi også kroppen aktivt i undervisningen. Det sker gennem øvelser som er tæet knyttet til kommunikationsfaget, men også gennem såkaldte energizere.

Energizere er små øvelser, som tager mellem to og ti minutter. Det er små oaser, hvor hjerne, hjerte og krop bliver aktiveret. Vi bruger energizere til f.eks. at hæve energiniveauet, skærpe koncentrationen, til at fremme kendskabet til hinanden og fă dialogen i gang. Når vi underviser i mundtlig kommunikation, bruger vi energizere, der sætter gang i improvisation og brug af stemme eller kropssprog på nye måder. Men vi inddrager også kroppen, når fagene har mere teoretisk karakter. Her laver vi bl.a. energizere, der skaber positiv stemning og øger trygheden i læringsrummet. Et eksempel er energizeren "Møder , der fungerer ved, at de studerende bevæger sig rundt i lokalet. Hver gang vi ringer med klokken, finder de sammen to og to. Når alle har en makker, giver vi en instruktion, der får dem til at fortælle hinanden noget. Emnet kan med fordel have et positivt (eller pudsigt) fokus. Instruktionen kan f.eks. lyde: "I skal på skift fortalle om en positiv oplevelse, vi har haft inden for det sidste døgnn.. Man kan også vælge emner, der knytter sig mere konkret til undervisningen, f.eks: "Hvad kan du iser godt lide ved at gå på dette studie? " eller: "Hvad er den vigtigste pointe, du tager med hjem $i$ dag? «. Når begge parter har fortalt, siger de tak til hinanden, og går igen rundt i lokalet indtil klokken ringer næste gang. På fem minutter får de mødt flere af de andre studerende på workshoppen, og samtidig făr de bevæget kroppen.

Når man kaster studerende ud på gulvet på denne 
måde, er det afgørende for succesen at forklare de studerende hensigten med den type øvelse. Første gang de oplever det, er de forståeligt nok lidt skeptiske. Men vi oplever, at når der efterfølgende bliver talt og grinet og stemningen i læringsrummet er præget af energi, bliver det tydeligt, at energizere lever op til deres navn.

\section{Afrunding}

Vi har i det ovenstående argumenteret for, at man kan fremme læringspotentialet i undervisningen ved at skabe et læringsrum, der opleves trygt og positivt af de studerende, og som indeholder aktiviteter, der skaber varierede dialogformer. I dette arbejde er det væsentligt at medtænke de kognitive, de følelsesmæssige, de sociale og de kropslige aspekter. Vi har givet eksempler på redskaber, der kan støtte den talte dialog i plenum eller i mindre grupper, og vi har givet eksempler på, hvordan skriftlig dialog kan inddrages i undervisningen. Ydermere har vi givet eksempler på, hvordan man kan lave aktiviteter, der skaber fysisk bevægelse i læringsrummet.

I vores undervisning på RUC $\mathrm{i}$ de forskellige dialogiske læringsrum oplever vi et liv, engagement og udvikling hos de studerende, som er unikt.Vi oplever, at prioriteringen af dialog og tid til refleksion ændrer hierarkier, så alle tager ordet og får sat gang i konstruktion af læring gennem refleksion og dialog med stoffet.Vi prioriterer de studerendes tid til dialog frem for lange, ordrige oplæg fra vores side og resultatet er et fagligt, socialt fællesskab med aktive, engagerede og fagligt stærke studerende.

\section{Referencer}

Carlsen, S. \& Juel, H. (2009). Mundtlighedens magi: Retorikkens didaktik, filosofi og laringskultur. København: Handelshøjskolens Forlag.

Dysthe, O. (1997). Det flerstemmige klasserum. Århus: Forlaget Klim.

Dysthe, O. Et al. (2001). Skrive for at leere - faglig skrivning $i$ de videregående uddannelser. Århus: Forlaget Klim.

Dysthe, O. (2003). Dialog, samspil og laring. Århus: Forlaget Klim.

Haugsted, M. Th. (2004). Taletid, mundtlighed, kommunikation og undervisning. Alinea, København.

Hundeide, K. (2003). Det intersubjektive rum. I Dysthe, O. (red.) Dialog, samspil og laring. Århus: Forlaget Klim.

Herskin, B. (1995). Undervisningsteknik for universitetslacere - formidling og aktivering. København: Samfundslitteratur.

Herskin, B. (1997). Undervisning i praksis - principper og metode. København: Teknisk Forlag A/S.

Illeris, K. (2003). Læringsrum I: Bjerg, J. (red.) Gads Psykologi Leksikon, Gads forlag

Illeris, K. (2006). Laring. Frederiksberg: Roskilde Universitetsforlag, 2. udgave.

Illeris, K. (2007). Voksenuddannelse og voksenlaring. Frederiksberg: Roskilde Universitetsforlag. (2. Udgave). København: Hans Reitzels Forlag.

Jeppesen, M.B. \& Ulstrup, E. (2009). De Dialogiske Læringsrum. I: Juel, H.: Kommunikationsfagets håndvoerk og teori, (red.). København: Handelshøjskolens Forlag.

Verdens 25 fedeste energizers. (2007). Center for arbejdsliv. Dansk teknologisk institut.

\section{Noter}

1 Olga Dysthe, norsk professor i praktisk pædagogik.

2 Knud Illeris, professor i Livslang Læring.

3 Kontekst vil i et sociokulturelt perspektiv sige, at alt er vævet sammen, alt er integreret og i denne sammenvævning indgår læring (Dysthe 2003:50).

4 Et begreb udviklet af Jerome Bruner, amerikansk kognitionspsykolog. Det illustrerer den støtte, andre giver den lærende i læringsprocessen. 